\title{
HUBUNGAN ANTARA ADVOKAT DENGAN KLIEN DALAM PENEGAKAN HUKUM PERDATA
}

\author{
Oleh : Risdalina, SH.MH \\ Dosen Tetap STIH Labuhanbatu \\ Email: risdalina@gmail.com
}

\begin{abstract}
ABSTRAK
Pada prinsipnya tugas seorang Advokat/ Penasehat Hukum adalah memberikan nasehat atau pembelaan dalam arti luas, tugas utama seorang Advokat adalah memberikan pelayanan kepada Klien /Penerima Jasa Hukum. Dalam proses peradilan Perdata, meskipun salah satu asasnya mengatakan dalam perkara perdata tidak harus diwakilkan dalam persidangan, akan tetapi usaha pendayagunaan hak bantuan hukum bagi masyarakat yang buta akan hukum inilah lazimnya sangat diperlukan jasa hukum dilakukan oleh penasihat hukum/advokat.

Dalam Peradilan Perdata Advokat / Pengacara berkedudukan sebagai kliennya atau Kuasa Hukumnya yang mewakili dirinya pada persidangan di Pengadilan, sebagai landasan hukum Advokat dalam Peradilan Perdata adalah pasal 123 ayat 1 HIR (Herziene Indonesisch Reglement) mengatakan Bilamana dikehendaki kedua belah pihak dapat dibantu atau diwakili oleh Kuasa yang dikuasakannya untuk melakukan itu dilakukan dengan Surat Kuasa Khusus. Namun fungsi Advokat tidak hanya sebatas dalam pengadilan saja, akan tetapi juga diluar persidangan. Hubungan Advokat/Pengacara dengan Klien adalah membantu pihak-pihak yang berperkara yang buta tentang hukum dalam mempertahankan hukum perdata materil di persidangan. Bagi seorang Advokat / Pengacara Hukum Perdata merupakan interprestasi ilmiah guna mempertahankan unsur-unsur hukum acara perdata, antara Advokat dan Klien sepakat tentang penangan perkara maupun tentang honorarium sebaiknya dibuat dalam akta perjanjian, agar terhindar dari hal-hal yang tidak dinginkan dikemudian hari.

Adapun permasalahan dalam makalah ini adalah 1. Bagaimana fungsi dan peran seorang Advokat menurut UU Nomor : 18 tahun 2003. 2. Bagaimana Hubungan Advokat dengan Klien serta akibat hukumnya dalam Penegakan Hukum Perdata. Sedangkan Tujuan penelitian ini adalah untuk mengetahui fungsi dan peran Advokat serta akibat hukumnya dengan Klien dalam Penegakan Hukum perdata. Adapun metode yang digunakan dalam penelitian ini adalah menggunakan metode yuridis normatif, yaitu melalui buku-buku maupun peraturan yang berkaitan dengan permasalahan diatas. Hubungan Advokat / Penasehat Hukum dengan Klien dalam membela dan melindungi hak-hak kebebasan fundamental dan pencari keadilan, di Indonesia telah mendapat landasan hukum yang telah diakui keberadaannya melalui Undang-Undang Nomor : 18 tahun 2003 tentang Advokat.
\end{abstract}

Kata Kunci : Advokat, Klien dan Penegakan Hukum Perdata

\section{PENDAHULUAN}

\subsection{Latar Belakang Masalah}

Advokat berasal dari bahasa latin yaitu Advocare, yang artinya to defend (mempertahankan), sedangkan dalam bahasa Inggris, pengertian Adovat dijelaskan kata Advocate ( menandai adanya atau merekomendasikan di depan umum ). Selain itu istilah Advokat diartikan sebagai orang yang melaksanakan kegiatan advokasi yang dilakukan seseorang atau kelompok untuk memperjuangkan hak kliennya/ penerima jasa hukum, baik perorangan maupun kelompok berdasarkan peraturan perundang - undangan, oleh karena itu diperlukan adanya profesi Advokat yang bebas, mandiri dan bertanggung jawab yang jujur, adil dan memiliki kepastian hukum bagi semua pencari keadilan dalam 
penegakan hukum, kebenaran, keadilan dan HAM

Advokat merupakan sebuah profesi dalam bidang hukum sudah dikenal di Indonesia sejak zaman Belanda dengan nama Reglemen op de Rechterlijke organisatie en het Beleid der Justitie in Indonesia, kemudian pada tahun 1947 di Indonesia diperkenalkan suatu peraturan yang mengatur tentang Advokat atau Procureur.

Di Indonesia Advokat diterjemahkan sebagai Lawyer, terkadang diartikan sebagai "Pengacara", atau Pembela, atau Penasehat Hukum, Pokrol, aau disebut juga "adjuster". Namun yang lebih sering digunakan adalah Advokat, Pembela, Pengacara, dan Penasehat Hukum". Istilah tesebut hanyalah persoalan penyebutan, akan tetapi mempunyai muara yang yang sama yaitu profesi di bidang penyediaan jasa hukum (Legal Profession).

Dalam pasal 1 ayat 1, Undang-Undang Nomor: 18 tahun 2003 maupun Kode Etik Advokat Indonesia tahun 2002, dijelaskan Advokat adalah orang berprofesi memberikan jasa hukum, baik didalam maupun diluar Pengadilan yang telah memenuhi persyaratan sebagaimana diatur undang-undang. Profesi Advokat merupakan jabatan mulia (officium nobile) diberikan karena aspek kepercayaan dari pemberi kuasa atau klien yan dijalankan untuk mempertahankan serta memperjuangkan hak-haknya di forum yang telah ditentukan, oleh sebab itu seorang Advokat hampir seluruh dunia kata atau istilah itu dikenal. Akan tetapi pada awalnya di Indonesia profesi penyedia jasa hukum sering dikenal dengan sebutan Penasehat Hukum, penggunaan istilah tersebut mengacu pada KUHAP, UU MA dan UU Peradilan Umum. Seiring waktu sebutan Penasehat Hukum mengalami pergeseran . Istilah Advokat mulai digunakan sebagi penyebutan penyedia jasa hukum dan istilah tersebut menjadi baku setelah keluarnya Undang-Undang Nomor: 18 tahun 2003 tentang Advokat.

Undang-Undang Nomor: 18 tahun 2003 tentang Advokat dijelaskan bahwa, Advokat adalah penegak hukum yang mempunyai kedudukan yang setara dengan penegak hukum lainnya, seperti Hakim, Jaksa dan Polisi, namun demikian meski sama - sama sebagai penegak hukum memiliki peran dan fungsi yang berbeda, karena Hakim mewakili kepentingan negera, sedangkan Jaksa dan Polisi mewakili kpentingan Pemerintah, namun demikian peran Advokat tidak termasuk dalam lingkaran kekeuasaan tersebut. Namun Advokat sebagai penegak hukum menjalankan peran dan fungsinya mandiri untuk mewakili kepentingan masyarakat (Klien) dan tidak terpengaruh kepada kekuasaan negara (yudikatif maupun eksekutif).

Istilah Klien adalah orang, badan hukum, atau lembaga lain yang menerima jasa hukum dari advokat, sedangkan jasa hukum yang diberikan Advokat berupa konsultasi hukum, bantuan hukum, menjalankan kuasa, mewakili, mendampingi, membela dan melakukan 
tindakan hukum lain untuk kepentingan hukum klien.

Dalam memberi jasa hukum, seorang pengacara dituntut untuk mempunyai konsep manajemen dalam mengelola kantor hukumnya. Oleh sebab itu seorang pengacara dalam menjalankan bisnis kepengacaraan, seorang pengacara dilindungi dalam menjalankan tugas dan tanggung jawab dalam membela kepentingan kliennya dibatasi dengan Kode Etik dan UU Advokat.

Seorang Pengacara, Advokat mewakili Klien dalam menyelesaikan suatu kasus hukum baik didalam mapun diluar persidangan. Di Indonesia seorang pengacara atau Advokat haruslah berpendidikan Sarjana Hukum , serta mengikuti Pendidikan Khusus Advokat ( PKPA ) dan lulus ujian yang dilaksanakan suatu organisasi Pengacara dan mengikuti magang selama 3 tahun dari Kantor Hukum serta sebagai pendaping nya adalah seorang Advokat yang telah bercara minimal selama 7 tahun.

Adapun perbedaan antara Perbedaan Advokat, Pengacara dan Penasehat Hukum sebagai berikut:

a. Advokad dalam sudut pandang pribadinya, ia mewakili kepentingan masyarakat (klien) untuk membela hak-hak hukumnya. Namun, dalam membela hak-hak hukum tersebut, cara berpikir advokat harus objektif menilainya berdasarkan keahlian yang dimiliki dan kode etik profesi. Untuk itu, dalam kode etik ditentukan diantaranya, advokat boleh menolak menangani perkara yang menurut keahliannya tidak ada dasar hukumnya, dan advokad dilarang memberikan informasi yang menyesatkan dan menjanjikan kemenangan kepada klien. Sebelum berlakunya Undang-Undang Nomor 18 Tahun 2003 tentang Advokat, pengertian advokat adalah seseorang yang memiliki profesi untuk memberikan jasa hukum kepada orang di dalam pengadilan atau seseorang yang mempunyai izin praktek beracara di pengadilan di seluruh wilayah Negara Republik Indonesia. Sedangkan yang dimaksud dengan pengacara biasa adalah seseorang yang memiliki profesi untuk memberikan jasa hukum di dalam pengadilan di lingkup wilayah yang sesuai dengan izin pratek beracara yang dimilikinya. Karena itu, apabila pengacara tersebut akan beracara di luar lingkup wilayah izin prakteknya, untuk itu ia harus meminta izin terlebih dahulu ke pengadilan dimana ia akan beracara.

b. Penasehat Hukum Penasehat hukum atau solicitor dapat diartikan sebagai orang yang bertindak dalam memberikan nasehatnasehat dan pendapat hukum terhadap suatu tindakan ataun perbuatan hukum yang akan dan yang telah dilakukan oleh kliennya (non-litigation)

Konsultan Hukum, Pengertian dari Konsultan hukum adalah yang berspesialisasi dalam hukum korporasi dalam menjalankan praktek profesinya berdasarkan surat izin usaha yang khusus yang diberikan oleh yang 


berwenang tidak di muka

pengadilan. Konsultan Hukum, pada umumnya bekerja untuk pekerjaan-pekerjaan hukum yang berkaitan dengan bidang usaha. Dalam melaksanakan tugasnya, seorang Konsultan Hukum haruslah memiliki pengetahuan mengenai aspek hukum kontrak, hukum pajak, accounting, hukum sekuritas, kebangkrutan, hak kekayaan intelektual, lisensi, hukum penetapan wilayah, dan hukumhukum yang spesifik kepada kepentingan bisnis korporasi dimana mereka bekerja.

\subsection{Rumusan Masalah}

Berdasarkan uraian diatas, menjadi pokok permasalahan yang ingin diteliti dan di bahas dalam penelitian ini adalah sebagai berikut:

1. Bagaimana fungsi dan peran seorang Advokat menurut Undang-Undang Nomor 18 tahun 2003?

2. Bagaimana Hubungan Advokat dengan Klien dan Akibat hukumnya dalam Penegakan Hukum Perdata?

\subsection{Tujuan Penelitian}

Berdasarkan dari latarbelakang serta perumusan masalah tersebut diatas, maka tujuan dari penelitian ini adalah sebagai berikut:

1. Untuk mengkaji fungsi dan peran seorang Advokat menurut Undang-Undang Nomor 18 tahun 2003.
2. Untuk mengkaji Hubungan Advokat dengan Klien dan Akibat hukumnya dalam Penegakan Hukum Perdata.

\section{PEMBAHASAN}

\subsection{Fungsi dan Peran Advokat Menurut Undang-Undang Nomor 18 tahun 2003}

Dalam pasal 1 ayat 1, Undang-Undang Nomor : 18 tahun 2003 maupun Kode Etik Advokat Indonesia tahun 2002, dijelaskan Advokat adalah orang berprofesi memberikan jasa hukum, baik didalam maupun diluar Pengadilan yang telah memenuhi persyaratan sebagaimana diatur undang-undang. Profesi Advokat merupakan jabatan mulia ( officium nobile ) diberikan karena aspek kepercayaan dari pemberi kuasa atau klien yan dijalankan untuk mempertahankan serta memperjuangkan hak-haknya di forum yang telah ditentukan. Jasa hukum yang dimaksud dalam undangundang tersebut adalah bentuk jasa yang diberikan seorang advokat, mulai dari Konsultasi Hukum, Bantuan Hukum, menjalankan Kuasa, Mewakili, Mendampingi, Membela dan melakukan tindakan hukum lain untuk kepentingan hukum klien/ Penerima Jasa Hukum.

Dengan demikian pelayanan yang diberikan seorang Advokat bersifat luas, meliputi bidang litigasi atau dalam pengadilan maupun non litigasi atau diluar pengadilan. Sejak berlakunya UU Nomor : 18 tahun 2003 tentang Advokat, profesi Advokat eksistensinya telah diakui sebagai penegak 
hukum lainnya . Sejatinya keberadaan profesi Advokat secara formal telah diakui di Indonesia.

UU Nomor : 18 tahun 2003 tentang Advokat telah dijelaskan bahwa, upaya mewujudkan prinsip-prinsip negara hukum dalam berkehidupan bermasyarakat dan bernegara, peran dan fungsi Advokat sebagai profesi yang bebas dan mandiri serta bertanggung jawab merupakan bagian yang terpenting.

Tugas seorang Advokat melalui jasa hukum bertujuan demi tegaknya keadilan dan supremasi hukum untuk kepentingan masyarakat yang membutuhkan keadilan. Profesi Advokat juga memberikan sumbangsih bagi pemberdayaan masyarakat serta pembaharuan hukum di Indonesia, terutama di bidang ekonomi dan perdangan, termasuk penyelesaian sengketa diluar pengadilan. Usaha tersebut melalui jasa konsultasi, negoisasi, maupun membuat kontrak-kontrak dagang.

Sesuai ketentuan pasal 5 ayat $1 \mathrm{UU}$ Nomor :18 tahun 2003, menyebutkan memberikan sstatus kepada Advokat sebagain penegak hukum yang kedudukannya setara dengan penegak hukum lainnya ( Hakim, Jaksa, Polisi ) dalam menegakkan hukum dan keadilan. Dengan demikian seorang Advokat selalu dilibatkan langsung dalam setiap proses hukum baik Pidana, Perdata, Tata Usaha Negara.

Peran dan Fungsi seorang Advokat sangat kompleks, selain memiliki fungsi secara individu dan organisasi, seorang Advokat memiliki peran yang sangat besar untuk bangsa dan negara dalam penegakan hukum di Indonesia.

Sebagai seorang harus memenuhi Syarat- Syarat menjadi Advokat. Dalam UU Nomor:18 tahun 2003, tentang Advokat menjelaskan bahwa syarat-syarat dan memumum bahwa “ yang diangkat sebagai advokat adalah berpendidikan dengan latar belakang Sarjana Hukum dan setelah mengikuti pendidikan khusus Advokat yang dilaksanakan organisasi“.

Pasal 3 ayat 1 menyatakan bahwa, untuk diangkat sebagai advokat harus memenuhi syarat sebagai berikut :

1. Warga Negara Republik Indnesia

2. Bertempat tinggal di Indonesia

3. Tidak berstatus sebagai Pegawai Negeri

4. Berusia sekurang kurangnya 25 tahun

5. Berlatar Pendidikan Sarjana Hukum

6. Lulus ujian yang diadakan organisasi advokat

7. Magang 2 (dua) tahun terus menerus pada kantor advokat

8. Tidak pernah dipidana karena melakukan tindak pidana kejahatan yang diancan pidana penjara 5 (lima ) tahun

9. Berperilaku baik, jujur bertanggung jawab, adil, dan memiliki integritas yang tinggi.

Peran dan Fungsi Advokat bagi Negara yaitu:

1. Advokat berfungsi sebagai pengawal konstitusi dan Hak Asasi Manusia 
2. Advokat sebagai pioneer dalam memperjuangkan Hak Asasi Manusia yang merupakan hak paling dasar dari warga negara.

3. Advokat sebagai anak bangsa yang berkewajiban untuk menjaga keutuhan bangsa dan negara.

Peran dan Fungsi Profesi advokat untuk Diri Sendiri dan Organisasi:

1. Melaksanakan kode Etik Advokat

2. Memegang teguh sumpah Advokat

3. Menjunjung tinggi idealism, kebenaran dan keadilan

4. Menjaga kemandirian, kekebasan, derajat dan matabat advokat

5. Meningkatkan mutu pelayanan

6. Menjaga persatuan dan kesatuan advokat.

Selain peran dan fungsi diatas, seorang advokat sebagai salah satu elemen penegak hukum mempunyai peran sebagai penyedia jasa hukum serta pemberi bantuan hukum.

\section{- Advokat Sebagai Pemberi Bantuan} Hukum Secara Cuma - Cuma

Dalam UU Nomor : 18 tahun 2003 tentang Advokat dijelaskan bahwa, seorang advokat wajib memberi antuan ukum secara Cuma - Cuma kepada pencari keadilan yag tdak mampu / miskin, akan tetapi bantuan hukum secara Cuma-Cuma tidak boleh berdasarkan atas rasa belas kasihan, karena perbuatan itu lebih kepada peghargaan terhadap HAM dalam mewujudkan keadilan dalam masyarakat.

Bantuan hukum secara suma-Cuma adalah jasa hukum yang diberikan seorang advokat tanpan menerima pembayaran honorarium, bantuan tersebut berupa pemberian konsultasi hukum, mewakili, menjalankan kuasa, membela, mendampingi, serta melakukan tindakan hukum lainnya untuk kepentingan bagi pencari keadilan yang tidak mampu di setiap proses pradilan, sesuai dengan pasal 1 ayat 1 peraturan PERADI Nomor : 1 tahun 2010 tentang petunjuk Pelaksanaan Pemberaian Bantuan Hukum Secara CumaCuma.

Pemberian bantuan hukum di muka pengadilan berupa bantuan hukum litigasi meliputi seluruh rangkaian proses peradilan, mulai dari perkara perdata, pidana maupun tata usaha negara, termasuk dalam proses pelaporan dan pemeriksaan di kepolisian dan penuntutan di kejakaan terkait perkara pidana.

Pasal 4 ayat 1 PP Nomor: 8 tahun 2008 tentang persyaratan dan Tata Cara Pemberian Bantuan Hukum secara CumaCuma, menerangkan pemberian bantuan hukum secara Cuma-Cuma terlebih dahulu mengajukan permohonan secara tertulis yang ditujukan kepada advokat atau melalui organisasi atau Lembaga Bantuan Hukum.

\subsection{Hubungan Advokat dengan Klien dan} Akibat Hukumnya dalam Penegakan

\section{Hukum Perdata}

Seorang Advokat dalam beracara pada peradilan perdata, dimana Advokat/Pengacara berkedudukan sebagai kuasa atau wakil 
kliennya. Landasan hukum advokat dalam peradilan perdata adalah Pasal 123 HIR (Herziene Indonesisch Reglement) dimana dalam Pasal 123 ayat (1): " Bilamana dikehendaki, kedua belah pihak dapat dibantu atau diwakili oleh kuasa yang dikuasakannya untuk melakukan itu dengan surat kuasa.

Oleh karenanya Pasal 123 HIR ini, hukum acara perdata mengenal adanya sistem lembaga perwakilan. Sehingga peran Advokat/Pengacara dapat membantu pihakpihak yang berpekara dalam mempertahankan hukum perdata materiil. Hukum perdata bagi seorang Advokat adalah seorang interprestasi dan perang ilmiah, karena itu sebagai Advokat wajib mempertahankan unsur-unsurnya di dalam hukum acara perdata.

Dasar adanya sistem lembaga perwakilan adalah dikarenakan masih banyaknya pencari keadilan yang kurang mampu atau kurang memahami dalam mengajukan gugatan dan tangkisan dengan rumusan sedemikian rupa. Oleh karena itu, lembaga perwakilan bermaksud menjaga agar jangan sampai pihak-pihak pencari keadilan dirugikan hanya membuat kesalahankesalahan dalam hukum acara perdata yang terikat oleh banyaknya peraturan dan macammacam formalitas.

Oleh karena itu, sebagai advokat yang bertindak untuk dan atas nama kliennya diharuskan memiliki kemampuan dan keberanian berpekara, apalagi mengingat kliennya telah memberikan kepercayaan yang besar padanya. Hal ini disebut sebagai keterampilan profesional, sedangkan keberanian berperkara dimaksudkan untuk berhadapan dengan lawan dan hakim di pengadilan. Tugas advokat sebagai lembaga perwakilan adalah menyaring dan menyusun kejadian-kejadian yang ia peroleh dari kliennya, kemudian ia kumpulkan sebagai bahan untuk nantinya dituangkan dalam bentuk gugatan, yang akan dimajukan dalam sidang pengadilan.

Namun fungsi advokat sebenarnya tidak hanya terbatas di dalam pengadilan, tetapi juga di luar pengadilan. misi seorang advokat adalah memberikan bantuan hukum berdasarkan undang-undang kepada kliennya. Selain perannya beracara di pengadilan (perdata), di masa modern sekarang ini, adalah perannya dalam membuat "memorandum hukum" atau legal audit (pemeriksa hukum), dan legal opinion (pendapat hukum) dalam menangani kasus yang dihadapi klien.

Pada prinsipnya, tugas advokat adalah memberikan nasehat dan pembelaan dalam arti menurut hukum kepada kliennya. Namun demikian, dalam menjalankan perannya itu, advokat mempunyai fungsi yang lebih luas lagi daripada hanya sekedar menjadi penasehat dan pembela, yakni harus mempunyai tugas dan tanggung jawab untuk memajukan profesi hukum, peradilan dan hukum dalam arti luas. Yang dimaksud lembaga perwakilan diatas tidak termasuk orang-orang yang menurut hukum materiil tidak atau belum dapat bertindak sendiri dalam hubungan hukum, dan tidak dapat pula menghadap sendiri di muka 
Hakim, yang mereka itu diwakili oleh walinya atau wakilnya menurut hukum, seperti anak di bawah umur dan orang dewasa yang sakit jiwanya. Bukan pula yang dimaksudkan dengan perwakilan badan hukum oleh pengurus dan direksinya, dan tidak termasuk ketentuan Pasal 123 ayat 2 HIR yang menyebutkan seorang Jaksa mewakili pemerintah di muka pengadilan perdata.

Seorang Pengacara Perdata dapat beracara pada Pengadilan Negeri, Pengadilan Agama maupun Peradilan Tata Usaha Negara yang menangani perkara Perdata. Sesuai arti dari hukum perdata, dia lebih menekankan pada hubungan yang bersifat privat baik antara orang dengan orang dengan korporasi maupun korporasi dengan korporasi.

Penanganan atas kasus/perkara itulah disebut dengan Pengacara Perdata. Seorang pengacara Perdata harus lebih jeli melihat dan menganalisa perkara yang akan ditanganinya, seorang Pengacara perdata harus jeli atas perkara yang akan ditanganinya apakah termasuk dalam kategori Perbuatan Melawan Hukum atau Wanprestasi. Ketidakpahaman dalam memahami makna keduanya (wanprestasi atau perbuatan melawan hukum) mengakibatkan perkara yang ditanganinya tidak dapat diterima dengan baik atau ditolak oleh Majelis Hakim yang memeriksa dan mengadilinya.

Pengacara Perdata lebih banyak berhubungan dengan hal yang berkaitan dengan kerugian yang diderita oleh Klien baik materiil maupun immateriil yang diakibatkan oleh ingkar janjinya (wanprestasi) maupun perbuatan melawan hukum yang dilakukan oleh orang maupun sebuah korporasi atas hakhak yang semestinya didapat atau tidak didapat oleh seseorang atau sebuah korporasi. Atas dasar itulah seseorang maupun korporasi dapat mengajukan atas kerugian yang dideritanya secara Perdata baik ke Pengadilan Negeri maupun Pengadilan Agama setempat sesuai dengan Konpetensi Absolut dan Relatif sesuai yang diatur dengan Peraturan PerundangUndangan.

Pengacara Perdata harus memahami dua hal besar tentang unsur-unsur perbedaan dari Perbuatan Melawan Hukum atau Wanprestasi. Apabila sorang Pengacara tidak dapat memahami perbedaan keduanya, maka sangat sulit untuk dapat memenangkan perkara yang akan atau sedang dihadapi di Pengadilan. Karena pada umumnya Gugatan yang diajukan oleh seseorang maupun Korporasi di Pengadilan dalam perkara perdata adalah terdiri dari 2 (dua) bagian, yakni kalau tidak Perbuatan Melawan Hukum (PMH) atau Wanprestasi (Ingkar Janji).

Dalam mengajukan gugatan, harus deperhatikan dengan benar bahwa yang diberi kuasa menurut hukum harus benar-benar orang yang dapat mewakili yan bersangkutan dalam perkara tersebut dan telah memenuhi syaratsyarat untuk mewakili para pihak yang berperkara dengan sah dan berdasarkan hukum. Jika advokat telah diberi kuasa sebagai wakil, maka sipemberi kuasa tidak lagi memiliki hak untuk bicara dalam persidangan. 


\section{- Kode Etik Advokat}

Seorang Advokat dalam menjalankan tugasnya sangat erat hubungannya dengan prilakunya dalam profesinya . Prilaku merupakan etika,moral tingkah laku seseorang yang dilihat dari kacamata baik dan buruk. Kata Etika sama dengan moral keduanya memiliki arti adat kebiasaan yang mengatur tingkah laku. Perbedaan keduanya terdapat asal bahasanya, dimana etika basal dari bahasa Yunani, sedangkan moral berasal dari bahasa Latin.

Menurut Immanuel Kant yang diterjemahkan Lili Tjahyadi (Penerapan Kode Etik Advokat sebagai salah satu Bentuk Ketahanan Moral Profesi Advokat) membagi dua moralitas yaitu :

1. Moralitas Hetronom, yaitu sikap dimana kewajiban itu ditaati dan dilaksanakan karena berasal dari luar kehendak sipelaku sendiri. Misalnya karena ingin mencapai tujuan yang diharapkan atau karena takut pada penguasa yang memberi tugas kewajiban tersebut.

2. Moralitas Otonom, yaitu kesadaran manusia akan kewajiban yang ditaatinya sebagai kehendaknya sendiri. Inilah yang mnejadi prinsip moralitas, sebab berkaitan dengan kebiasaan tingkah laku manusia.

Dalam perkembangan profesi hukum di Indonesia banyak dibutuhkan masyarakat. Misalnya: Kepolisian, Kejaksaaan, Kehakiman, Notaris dan Advokat,sehingga memicu kebutuhan jasa hukum semakin meningkat. Namun dalam menjalankan tugasnya tidak bisa melakukan sesuai dengan kehendaknya sendiri akan tetapi Advokat harus memiliki aturan / pedoman sesuai dengan peraturan perundang-undangan.

Pedoman sebagai seorang Akdvokat dalam menjalankan tugas profesinya berupa Kode Etik Advokat, berawal dari pertemuan advokat menghasilkan sebuah kesepakatan berupa Piagam Baturraden pada tanggal 27 Juni 1971, isinya merumuskan tentang unsure penyebutan unsure seorang profesional antaranya :

1. Harus ada ilmu hukum yang dikembangkan didalamnya.

2. Harus ada unsur kebebasan didalamnya

3. Mengabdi pada kepentingan umum, tujuan utama bukan untuk mencari nafkah.

4. Ada hubungan kepercayaan antara Advokat dengan Klien.

5. Adanya kewajiban saling merahasiakan informasi dari Klien dan adanya jaminan akan kerahasiaan oleh undang-undang.

6. Adanya immuniteit terhadap penuntuttan tentang hak yang dilakukan dalam menjalankan tugas pembelaan.

7. Adanya kode etik dan peradilan kode etik

8. Adanya honorarium yang menyesuaikan kemampuan klien.

Kode etik advokat ditetapkan pada tanggal 23 Mei 2002, berdasarkan kesepakatan 7 (tujuh) organisasi advokat 
Indonesia, terdiri dari : IKADIN, AAI, AKHI, HKHPM (himpunan konsultan hukum pasar modal), SPI (serikat pengacara Indonesia), dan HAPI (himpunan advokat dan Pengacara Indonesia). Kode Etik Advokat Indonesia, maka setiap advokat menjungjung tinggi Kode Etik dan Sumpah Profesi yang pelaksanaannya diawasi Dewan Kehormatan, yang eksistensinya harus diakui setiap advokat tanpa melihat asal usul anggota organisasi profesinya, yang pada pengucapan sumpah profesinya tersirat pengakuan dan kepatuhan terhadap kode etik advokat, sehingga kepada setiap advokat dibebankan kewajiban untuk jujur dan bertanggung jawab dalam menjalankan profesinya baik kepada klien, teman sejawat, pengadilan, negara maupun masyarakat, sebagaimana tercantum dalam pembukaan Kode Etik Advokat Indonesia (KEAI) tahun 2002. Kode Etik Advokat berfungsi sebagai control dalam menjalankan tugas profesinya, sehingga ia diharapkan dapat menjaga martabat dan kehormatan profesinya.

- Hubungan Advokat dengan Klien dan Akibat Hukumnya

Seorang advokat dalam menjalin hubungan dengan klien memiliki aturan sebagaimana dirumuskan dam Kode Etik Advokat Indonesia, dimana seorang Advokat dalam menjalin hubungan dengan klien tidak serta merta semaunya sendiri, karena Advokat memiliki aturan yang telah dirumuskan dalam Kode Etik Advokat Indonesia.

Dalam pasal 18 UU Nomor : 18 tahun 2003 tentang Advokat, dalam menjalankan tugas profesional seorang Advokat dilarang membedakan perlakuan terhadap klien berdasarkan jenis kelamin, agama politik, keturunan, ras atau latar belakang sosial budaya

Dalam menjalankan tugas profesinya ada beberapa hal yang harus dipahami seorang Advokat dalam hubungannya dengan klien :

1. Seorang Advokat harus berupaya mencari solusi tercapainya kesepakatan dari kedua belah pihak, baik klien maupun pihak lawan agar sebisa mungkin memperoleh penyelesaian melalui jalan perdamaian.

2. Seorang Advokat tidak dibenarkan memberikan keterangan yng dapat menjerumuskan klien mengenai perkara yang sedang ditanganinya baik liasan maupun tertulis yang dapat mempersulit klien.

3. Selama menjalankan tugasnya Advokat berkewajiban mempertimbangkan kemampuan klien dalam menerima jasa hukum dalam menentukan honorarium

4. Seorang advokat tidak dibenarkan membebani kliennya dengan biaya yang tidak perlu

5. Seorang Advokat tidak dibenarkan memberikan jaminan kepada kliennya 
bahwa perkara yang ditanganinya pasti menang.

6. Selama menjalani profesinya seorang Advokat harus bersikap adil

7. Seorang Advokat harus menolak perkara yang diyakininya tidak ada dasar hukumnya.

8. Selama menjalankan tugas profesinya wajib memegang rahasia jabatan tentang segala hal yang diberitahukan oleh klien kepadanya ( kepercayaan ).

9. Seorang Advokat tidak dibenarkan melepaskan tanggung jawab yang dibebankan kepadanya yang tidak menguntungkan bagi klien

10. Seorang advokat yang mengurus kepentingan bersama lebih dari dua pihak maka ia harus mengundurkan diri dari mengurus kepentingan tersebut.

Pada perinsipnya tugas advokat adalah memberikan nasehat dan pembelaan dalam arti luas menurut hukum pada kliennya, namun demikian dalam menjalankan perannya seorang advokat mempunyai fungsi yang lebih luas dari pada hanya sekedar menjadi penasehat dan pembela yaitu mempunyai tugas dan tanggung jawab untuk memajukan profesi hukum , peradilan dan hukum dalam arti luas, akibat hukum antara Advokat dan Klien terjadi kontrak tereupatik dimana seorang Advokat dengan Ilmu pengetahuan hukumnya mewakili klien dalam menangani sengketa perdata, sedangkan klien diwajibkan membayar jasa hukum/honorium sebagaimana yang telah disepakati bersama.

\section{KESIMPULAN DAN SARAN}

\subsection{Kesimpulan}

Dalam Praktek menangani perkara perdata, seorang Advokat dan hubungannya dengan klien hanya sebagai kuasa dari klien yang memberi kuasanya kepada Advokat untuk menyelesaikan, membela hak-haknya baik didalam maupun diluar Pengadilan, baik kuasa Penggugat maupun kuasa Tergugat, serta pemberian kuasa antara klien dan Advokat haruslah berdasarkan kepercayaan. Oleh karena itu, sebagai advokat yang bertindak untuk dan atas nama kliennya diharuskan memiliki kemampuan dan keberanian berpekara, apalagi mengingat kliennya telah memberikan kepercayaan yang besar padanya. Bahwa, seorang Advokat kedudukannya sebagai subjek, karena ia ditunjuk oleh salah satu pihak untuk mewakili kepentingan kliennya dipersidangan, akan tetapi fungsi seorang Advokat adalah untuk membantu menyelesaikan perkara dipersidangan dengan menjunjung tinggi Pancasila, Hukum dan Keadilan. Disamping itu juga sesuai dengan Kode Etik Advokat. bahwa Advokat tidak arus mengutamakan kepentingan kliennya saja akan tetapi lebih mengutamakan tegaknya hukum, keadilan dan kebenaran.

\subsection{Saran}

Seorang advokat dalam menjalankan tugas dan profesi yang mulia mewakili kepentingan klien dalam membantu 
menyelesaikan perkara perdata dipersidangan

diharapkan tidak hanya melihat dari

honorarium semata mata, akan tetapi seorang Advokat dapat membantu peradilan hukum yang bersih dan berwibawa di Republik Indonesia yang kita cintai.

\section{BUKU}

\section{DAFTAR PUSTAKA}

Amir Yusuf, 2008, Strategi Bisnis jasa Advokat, Yogyakarta

Ishaq, 2010, Pendidikan Ke Advokatan, Sinar Grafika, Jakarta

Jimly Asshiddiqie, Peran Advokat dalam Penegakan Hukum. Jakarta
Prodjihamidjojo, Martiman. 1989, Penasehat Hukum dan Bantuan Hukum Indonesia Ghalia Indonesia., Jakarta

Rambe Popuan, Tekhnik Praktek advokat, 2001, Gracia, Bandung

Sartono \& Bekti Suryani, Prinsip Dasar Profesi Advokat, 2013, Jakarta

Winarta, Frans Hendra, 2002, Bantuan Hukum Suatu Hak Asasi Manusia Bukan Belas Kasihan, Media Komputindo, Jkt

\section{Peraturan Perundang-undangan}

Undang-Undang Nomor : 18 tahun 2003 tentang Advokat

Kode Eik Advokat Indonesia tahun 2002

Peraturan Peradi Nomor : 1 tahun 2010 tentang Pemberian Bantuan Cuma-cuma 